\title{
The mango in French-speaking West Africa
}

\author{
Jean-Yves ReY ${ }^{a *}$, Thierno Mamadou Diallo ${ }^{b}$, Henri VANNIÈRE$^{a}$, Christian DIDIER ${ }^{a}$, Sidiki KÉITA $^{c}$, Morodjan SANGARÉc
}

\author{
a Cirad, département Flhor, \\ UPR Productions fruitières \\ TA 50/PS4, Bd de la Lironde, \\ 34398 Montpellier Cedex 5, \\ France \\ jean-yves.rey@cirad.fr \\ b IER, URG, BP 30, Bamako, \\ Mali \\ ${ }^{\mathrm{C}}$ Irag, CRA Bordo, BP 352, \\ Kankan, Guinée
}

\section{The mango in French-speaking West Africa.}

Abstract - Introduction. The mango tree today, very appreciated in West Africa for its fruit and its shade, is, however, of recent introduction in Africa. The article presents the history of its expansion in the zone. Mango tree expansion in West Africa. Originating from India, the mango tree was reported for the first time in West Africa, in Senegal, in 1824. It was at the end of the XIXth century that the mango trees began to have a significant distribution, especially in the coastal zones. Their extension became significant during the first half of the xxth century. An Amélie mango tree introduced in Mali around the 1890s allowed the grafting of many trees, which were widely distributed in the bordering countries. At the end of the 1940s, collections were gradually established in the entire zone and, during the decade 1970-1980, every country in French-speaking West Africa had at least a collection of mango trees. Export trends. Mali was the first country to export mangos towards Europe, around the end of the 1960s. It was followed by Burkina Faso, Guinea, Senegal, and especially the Côte d'Ivoire, whose exports, of approximately $2500 \mathrm{t}$ at the beginning of the 1990s, were multiplied by 4.5 in 2000 . This fast growth of exports from the Côte d'Ivoire profited from the presence of a maritime front and of a mass effect created by pineapple and banana exports. Amélie for a long time constituted the main part of the exports of Mali, Burkina Faso and the Côte d'Ivoire. However, since 1971, experimental shipments of colored mangos have been successfully realized. With mango consumption becoming democratized in Europe, the choice of exported varieties was gradually tightened: Amélie, at the beginning of the harvest season, then Kent, Keitt and Palmer. Parallel to this varietal evolution, the packaging techniques were gradually modernized.

Francophone Africa / Mangifera indica / plant introduction / geographical distribution / exports

\section{La mangue en Afrique de l'Ouest francophone.}

Résumé - Introduction. Le manguier aujourd'hui très apprécié en Afrique de l'Ouest pour ses fruits et son ombrage est pourtant d'introduction récente en Afrique. L'article retrace l'historique de son expansion dans la zone. L'expansion du manguier en Afrique de l'Ouest. Originaire d'Inde, le manguier a été signalé pour la première fois en Afrique de l'Ouest, au Sénégal, en 1824. C'est à la fin du XIX ${ }^{\mathrm{e}}$ siècle que les manguiers ont commencé à connaître une diffusion significative, surtout dans les zones côtières. Leur extension deviendra importante pendant la première moitié du $\mathrm{xx}^{\mathrm{e}}$ siècle. Un manguier Amélie introduit au Mali vers 1890 fut à l'origine de nombreux plants greffés qui furent largement diffusés dans les pays limitrophes. Dès la fin des années 1940, des collections furent établies progressivement dans toute la zone et, au cours de la décennie 1970-1980, chaque pays d'Afrique de l'Ouest francophone possédait au moins une collection de manguiers. L'évolution des exportations. Le Mali fut le premier pays à exporter, vers la fin des années 1960, des mangues vers l'Europe. Il fut suivi par le Burkina Faso, la Guinée, le Sénégal, et surtout la Côte d'Ivoire, dont les exportations, d'environ 2500 t au début des années 1990, ont été multipliées par 4,5 en 2000. Cette croissance rapide des exportations ivoiriennes a bénéficié de la présence d'une façade maritime et d'un effet de masse créé par les exportations de bananes et d'ananas. Amélie a longtemps constitué l'essentiel des exportations du Mali, du Burkina Faso et de la Côte d'Ivoire. Cependant dès 1971, des expéditions expérimentales de mangues colorées furent réalisées avec succès. La consommation de mangues se démocratisant en Europe, le choix variétal s'est progressivement resserré : Amélie, en début de campagne, puis Kent, Keitt et Palmer. Parallèlement à cette évolution variétale, les techniques de conditionnement se sont progressivement modernisées.

Afrique francophone / Mangifera indica / introduction de plantes / distribution géographique / exportation 
"In the tropics, the mango plays a greater role for thousands than the apple in the regions of North America. "Popenoe quoted by France du Pavillon [1].

\section{Introduction}

The mango tree (Mangifera indica) so common in West Africa today is, on the contrary, a recent introduction to and development in the area. Although the mango is, along with citruses, one of the most widespread fruits in French-speaking Africa, the mango tree is also a highly prized shade tree, employed either to line city streets, or in isolation or groves in yards, gardens and public places. It can be considered a fruit tree providing shade or as an ornamental tree providing fruits.

This tree, perfectly integrated into the landscape and daily life of the inhabitants of West Africa, is well known to all. In early reading books for children, the drawing of a mango symbolises fruits, while the mango tree represents the trees under which the old men smoke their pipes. Its fruit plays an essential role in human diet. It is one of the rare - if not the only - fruit which can satisfy the greater part of the population at peak production [2]. With its richness in vitamins, it contributes to limiting deficiencies, in particular avitaminosis A, which causes blindness in children in the dry savannah areas where the oil palm is difficult to grow.

Our article retraces the history of the expansion of the mango tree in West Africa. It can be used as an introduction to agronomic research work on the plant, which will be the subject of future publications.

\section{The expansion of the mango tree in West Africa}

The mango tree originated in the Indo-Burmese region, where, according to de Candolle, it has been cultivated for 4000 years $[3,4]$. A representation of Buddha dating from 110 BC depicts him in the middle of a mango tree plantation $[4,5]$. The Emperor Akbar, who ruled India from 1556 to 1605 , had an orchard of 100,000 trees planted [5].
From India, the mango tree spread eastwards, towards Malaysia and South-East Asia, and to the West. The Arabs propagated it via the trading posts of the east coast of Africa. Ibn Battuta, "the great voyager of Islam", who was very familiar with mango trees after his voyages in India and the neighbouring archipelagos, states that in around 1330 the inhabitants of Mogadishu ate its fruit [6]: "They pour milk curds into a [...] saucer, and on top they put pickled lemons and peppers pickled in vinegar and brine, green ginger and mangoes, which look like apples, except that they have a stone. When the mango has reached maturity, it is extremely sweet and is eaten as a fruit; but before then it is bitter like a lemon, and it is pickled in vinegar".

Until the end of the 13th century, the West African coast saw no ships [7]. Indeed, unlike the East coast, where the winds blow six months in one direction, and for six months in another direction, on the west coast, the trade winds blow all year round in the same direction, from North-East to South-West in the North Hemisphere. Ships with a simple square sail could only sail with the wind at their backs, and so could only sail in one direction. In the 14 th century, thanks to the invention of the lateen sail, rudder and compass, maritime navigation made enormous progress. Navigators could now get their bearings and sail against the wind. By putting the west coast of Africa in contact with Europe, the east African coast, Asia and later America, these "great discoveries" had considerable consequences, for better or worse. They enabled the trade of plant material between the various parts of the world, which transformed the agricultural economies of the countries concerned.

Certain fruit species were quickly introduced to West Africa, such as orange trees, which were acclimated at several points along the coast from 1506 [8], lemons (citrons?) [8] or pineapples. On the other hand, mango trees are almost never mentioned in West Africa before the 19th century. René Caillié, who travelled from the estuary of the Rio Nuñez to Morocco via Timbuktu, between 1824 and 1828, passed through areas which today are populated by mango trees. As he ate dishes prepared locally by 
the inhabitants of the areas he passed through, he paid particular attention to the fruits and vegetables available in the markets and the gardens, which he described painstakingly when they were unknown to him. But, just like his predecessors - Park, Mollien, Mage, among others - he made no reference to mango trees [9].

\subsection{A late introduction}

Mango trees are mentioned in the Catalogue of nursery plants of the Government of Senegal, written in 1824 by Richard, the "head nursery gardener", who would give his name to the town of Richard-Toll [10]: "It is from there that it must have been introduced to Dagana, where it is mentioned in 1825 (Hardy, 1921, p. 187), and it was to Senegal that the Ministry applied to obtain mango stones for Algeria in 1833 (Hardy, 1921, p. 284)" [11].

But it was at the end of the $19^{\text {th }}$ century that fibre mangoes, or mangots, started to undergo significant distribution, especially in coastal areas: "Bérenger-Féraud (1873) mentions mangots in Gambia and le Corre states that they were in abundance and of great quality in Rio Nuñez and Rio Pongo in 1876" [11].

In the description of his journey from Niger to the Gulf of Guinea, in 1892, Binger [12] includes the mango tree on the list of fruit species present in West Africa: "the orange, mangot, lemon and jujube trees seem to have been imported from the West Indies". But, in the text, mango trees are only mentioned in the garden of Dabou military post (Côte d'Ivoire), by Lagoon Ebrié: "it is approached by a magnificent lane of mango trees, splendid trees laden with fruits, whose foliage does not let through a single ray of the sun". As this fort was built in 1853 and the post had been abandoned for twenty years in 1892, we may conclude that this lane was planted between 1855 and 1872. But, while he systematically describes the fruits he saw during his travels, the mango tree is never mentioned in the areas of the interior which he passed through between Saint-Louis, in Senegal, and GrandBassam, near Abidjan in Côte d'Ivoire, via
Kayes, Bamako, Ouagadougou, Kong and Bondoukou.

In 1899, Sébire, director of the test garden and prison of Thiès, in Senegal, wrote of mango trees [13]: "There are a good many in Casamance. It must have been the Portuguese who acclimated them. Certain nongrafted species are very good, but almost all have a lot of strings in the fruit and a strong odour of turpentine". His work contains a photograph of a Casamance landscape where the mango trees are probably about thirty years old. The same year, Toutee wrote [14]: "Dahomé receives all the trees imported by the Blacks coming back from Brazil, such as avocado trees, the countless and delicious mango tree tribe, orange and lemon trees".

In his Essay on the flora of French Guinea of 1906, Pobéguin [15] characterises the mango tree's habitat as: "the entire West coast (imported tree)". "The mango tree, which must have been imported a long time ago to the coast, is very common throughout the Lower Guinea region around indigenous villages.

Very old trees can also be found in places where there used to be villages". A photograph illustrating the work shows mango trees over 20 years old in Kindia, a town $150 \mathrm{~km}$ from Conakry. Pobéguin mentions the presence of mango trees in Conakry, but also in Kouroussa, in Upper Guinea.

In Mali, a mangot orchard was established in 1905 at Koulikoro, $60 \mathrm{~km}$ downstream of Bamako, on the left bank of the river Niger, by the first Malian agriculturalist.

So mangots were distributed along the coasts of West Africa in the second half of the 19th century. At the end of this century, they began to be part of the landscape in the coastal zones and penetrate towards the interior. Their coverage would become significant in the first half of the 20th century (figure 1).

\subsection{The success of the Amélie variety}

In his work of 1899, Sébire [13] mentions the grafted varieties present in the test garden of Thiès, in Senegal: Divine, Emonet, Julie, 


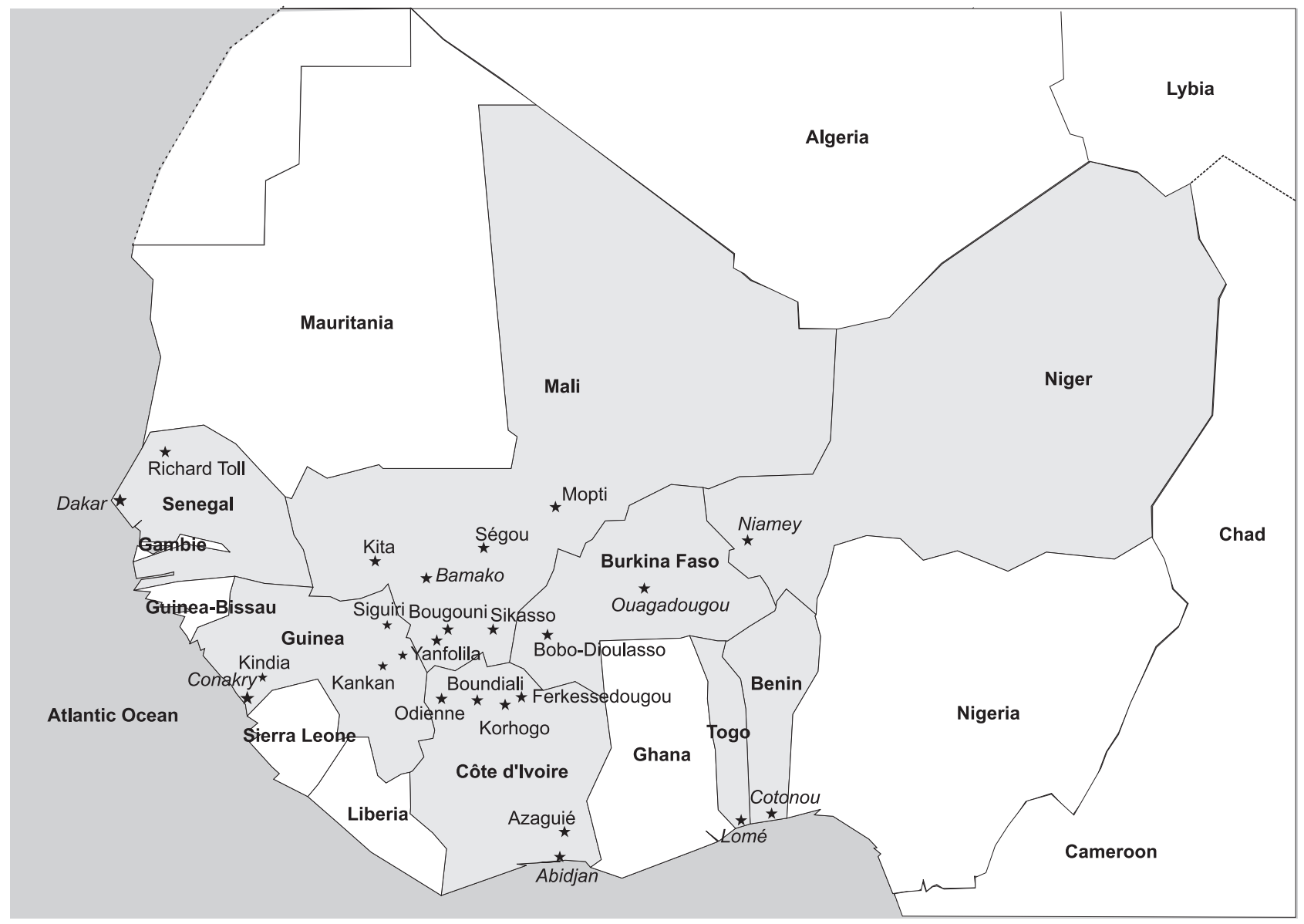

Figure 1.

Coverage area of the mango tree in French-speaking West Africa.
Reine-Amélie, Martin, Poignet Doré, Maldapik, Mangue d'Or, Sans-Pareille. In the test garden of Camayenne, near Conakry, H. Pobéguin mentions the grafted varieties in 1906: Manguier commun, Chinoise, Divine, Gordon, Gouverneur, Julie, Martin, Sabot and "unnamed" [15].

But the tree which had most impact on the development of grafted mango trees was an Amélie introduced to the catholic mission of Kita, in Mali, between Kayes and Bamako, in around 1890. The grafts from this tree and its descendants were distributed far and wide by catholic missions, State farms and various agricultural services. In Mali, this distribution was principally around Bamako and Koulikoro. Amélie mango trees were especially numerous near Bamako, in the direction of the upper Niger valley and in Baguinéda, where the State nurseries were located, and around Sikasso. But the Amélie variety was also present in most agricultural regions of the country, particularly in Ségou, where the Niger Office had established a great orchard, at Bougouni, Yanfolila and Koutiala.

The Amélie variety was also well distributed in the countries bordering Mali, in particular in West Burkina Faso (around BoboDioulasso, Orodara and Banfora), in Upper Guinea, at the catholic mission of SaintAlexis, at Siguiri and Kankan, and then in northern Côte d'Ivoire, at Ferkessédougou, Sinématiali, Korhogo, Dikodougou, Boundiali and Tengréla. This expansion took place from 1930 and accelerated after 1945. By the end of the 1960s, Amélie represented over $99 \%$ of the grafted mango trees in the 
Sudanian savannah regions. Only a few Julie trees (Muscat) or Sabot broke this monopoly.

\subsection{Variety collections}

The first significant collection of mango trees was established in Foulaya, near Kindia, in Guinea, between 1947 and 1952. The varieties mainly came from Guinea, the West Indies, Hawaii, Cameroon, Congo, Burkina Faso (Amélie), South-East Asia, Indonesia and Florida. Between 1955 and 1962, this basic collection was duplicated in numerous sites such as Maroua in Cameroon, Azaguié in Côte d'Ivoire, Bamako in Mali, Loudima in Congo and Dakar in Senegal.

In each country, the original collection was gradually expanded. So the Bamako collection received varieties from the Indian Ocean islands - Madagascar, Mauritius, Reunion - and from Florida. The collection of Foulaya subsequently received varieties from Côte d'Ivoire (the station of Lataha near Korhogo), and from Cameroon.

These materials in their turn served as a basis for the creation of new collections or wooded parks, as in Kaédi in Mauritania in 1971, Gabougoura near Niamey in Niger, in Togo in 1974 under the aegis of Togofruit, in the standard production units of the Burkina Faso fruit project or at Korhogo in Côte d'Ivoire in 1984

From the main collections, smaller collections were made. They included varieties which, a priori, best satisfied the requirements of the producers and markets. After 1970 , the criteria of this initial selection mainly concerned suitability for export to Europe. But as the responses of the cultivars under local conditions was then as little known as the properties desirable for exporting, the range of varieties preselected was ever changing and too wide to enable new selection steps. In general, the primary selection criterion was fruit colouring, and, consequently, these smaller collections essentially comprised the Florida varieties.

So, in Mali, a variety test set up in 1962 included eight varieties considered as the most promising for export - Zill, Irwin,
Smith, Kent, Keitt, Palmer, Valencia and Ruby - in comparison to Amélie, a local control. From 1970, the National Centre for Fruit Research $(\mathrm{CNRF})^{1}$ planted at Baguinéda, Yanfolila and Sikasso, multi-site orchards comprising the nine test varieties, each supplemented by a few others such as Beverly, Eldon or Brooks

In other countries, such as Senegal, the most grafted trees belonged to the Divine or Amélie varieties, and were known as "Mali mango" [15]. The distribution of mini-collections was more through private orchards, planters or missions than the research substations, which mainly used the top grafting technique. The composition of these multivariety orchards varied from country to country. Sensation and Tommy Atkins were part of the cultivars distributed to Senegal.

Finally, during the 1970s, each country in French-speaking West Africa had at least one collection of mango trees dependant on research organisations, development projects, public services such as agricultural services directorates or private planters.

These multi-variety orchards, in which the system was rarely randomised, were then used as a basis for the distribution of coloured fruit mango trees and played several roles: variety tests, demonstration orchards, providing grafts, etc. They were often associated with a nursery. From 1970, most private orchards were established with Florida varieties (Zill, Irwin, Smith, Kent, Keitt, Palmer, Valencia, Ruby, Haden, Beverly, Eldon, Brooks, Springfels, Davis Haden, Miami Late, Sensation) although, in certain areas, the tradition of Amélie plantations remained strong or even predominant.

The growth in exports, which will be deal with below, was achieved from an ever narrowing variety base: today, for the ships, exporters start their season with Amélie and then continue with Kent, Keitt and, to a lesser degree, Palmer. Other varieties, such as Irwin in Maritime Guinea or Valencia in Mali, are sent in small shipments by air.

\footnotetext{
1 The collection of the CNRF is today part of the Genetic Resources Unit of Mali's Institute for Rural Economics (IER).
} 
Figure 2.

Illustration of the dominance of mango exports originating in Côte d'Ivoire over those of other producer countries in West Africa from the beginning of the 1990s.

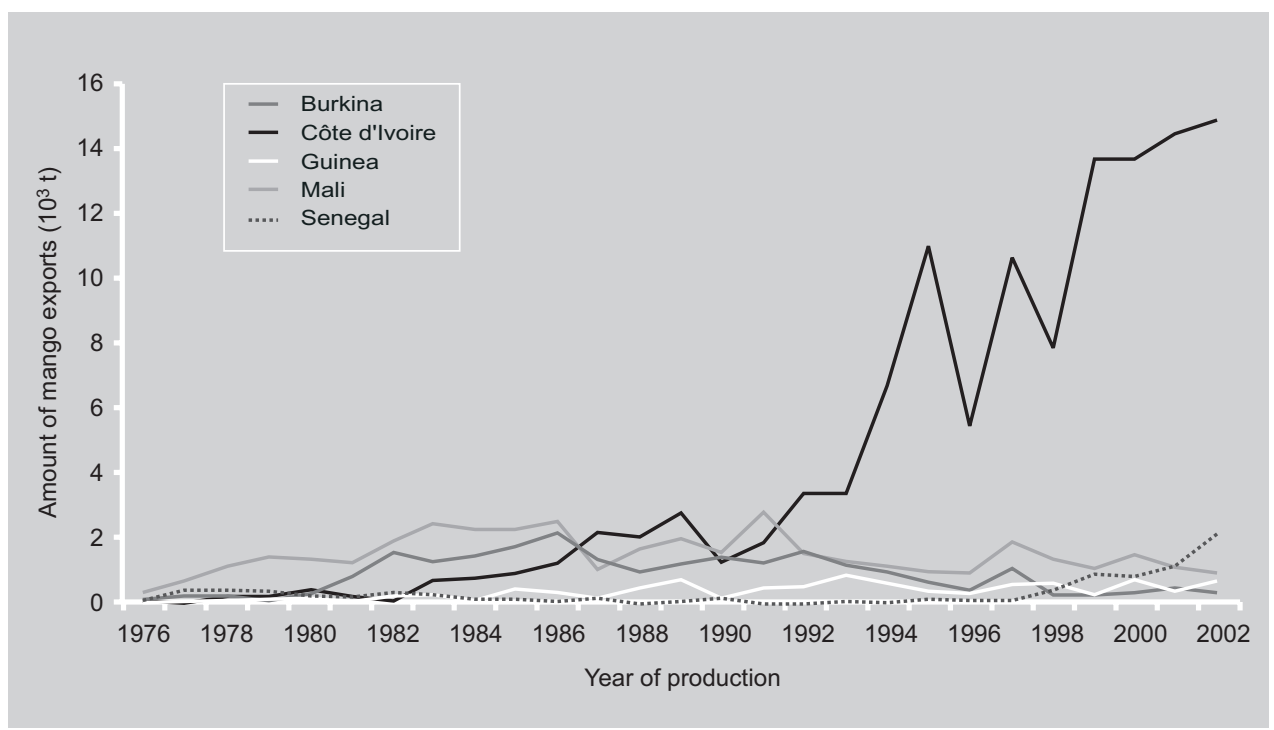

Consequently, in export fruit producing areas, new orchards have mainly been planted with Kent and, to a lesser degree, Keitt.

\section{Changing export trends}

The export data for mangoes from West Africa to the European Union (figures 2, 3) originates from customs statistics and relates to net weights. It should be qualified, as successive new accessions to the Union ${ }^{2}$ have incorporated into the statistics countries which were not there before. A few figures seem under-evaluated in relation to other sources (Côte d'Ivoire 1990, 1991 and 1996 or Mali 2002, for example), but overall this data is a good representation of trends observed in each exporting country.

\subsection{Exporting countries}

Mali was the pioneer in exporting mangoes to Europe, which began towards the end of the 1960s. Shipments were made by the fruits and vegetables section of Opam (Office for agricultural products of Mali), a

${ }^{2}$ Greece (1981); Spain, Portugal (1986) Austria, Sweden, Finland (1995).
State-owned company which then had the monopoly in exporting fruits and vegetables, with the technical assistance of the BDPA (Bureau for the development of agricultural production, in France).

The fruits, exclusively of the Amélie variety, were delivered in bulk in vans to the Opam packing station, which graded them, boxed them and shipped them by air. Later Opam was partially and then fully privatised under the name Fruitema, and lost its monopoly.

Mali remained West Africa's leading producer until 1986, when, after ceding first place to Côte d'Ivoire for four years, it regained the leading position in 1990 and 1991, when it reached its record with exports of $2144 \mathrm{t}$. Then, in spite of the installation of a well-equipped packing station at Sikasso, which enabled sea exports, its market share has constantly fallen, with total exports varying between 700 and $1450 \mathrm{t}$, depending on the year.

In Burkina Faso, exports began in the middle of the 1970s, driven by a development programme known as the "fruit tree project". They also shot up to reach $1627 \mathrm{t}$ in 1986, with two main exporters, the fruit tree project, which gave rise to Flexfaso, and an association of cooperatives, Ucobam. Since then, exports from this country have 


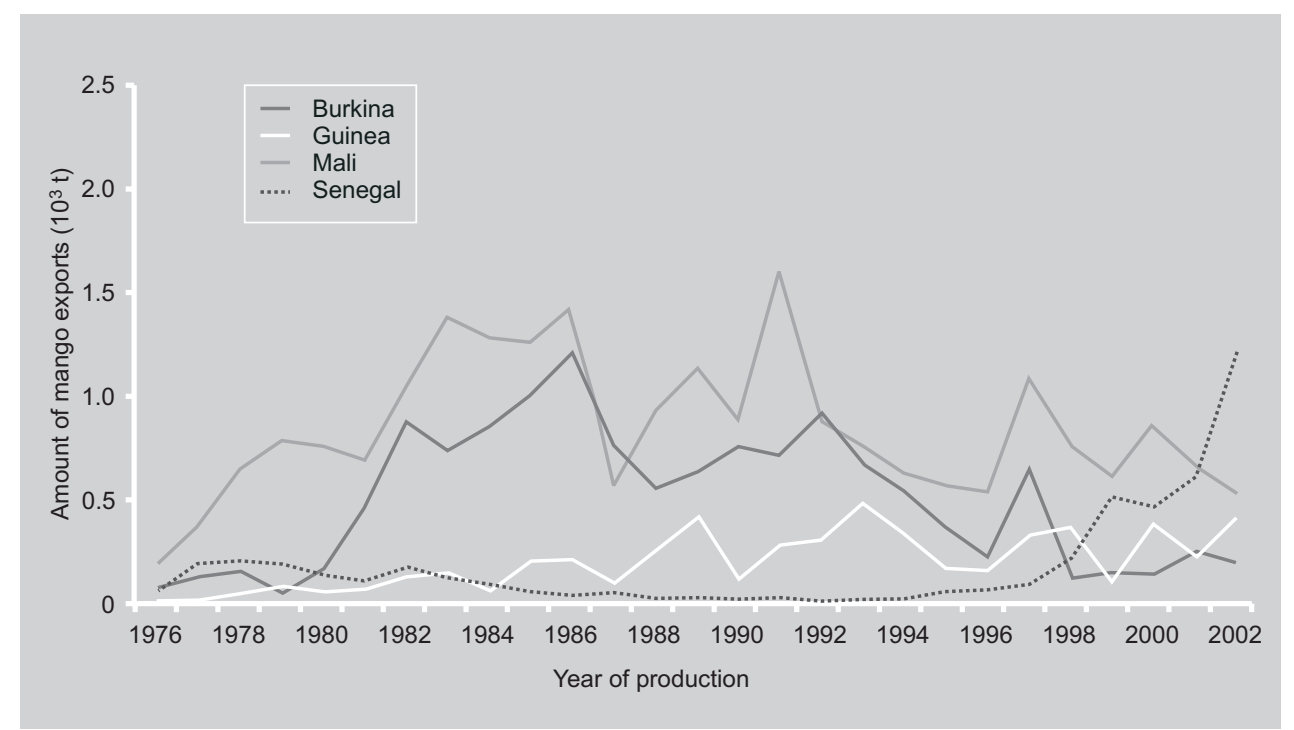

been falling constantly, especially from 1998 to 2002 .

Guinea started exporting towards the end of the 1970s. Its transcontinental shipments culminated in 1993, with 647 t. The numerous exporters were at this time supported by development projects, backed by international financing. Since then, exports, essentially made by one operator, have remained below 550 t. Nearly all fruits exported originate in Maritime Guinea.

Senegal exported less than $300 \mathrm{t}$ between 1977 and 1984, before a rapid decline, reaching $7 \mathrm{t}$ in 1992, and shooting upwards again from 1999, with $1627 \mathrm{t}$ in 2002 . The fruits mainly came from the coastal area to the North-East of Dakar, Niayes.

In Côte d'Ivoire, exports, which began at the end of the 1970s, increased starting from 1983 (figure 2). Since then, disregarding irregularities in production due to climate, they have been constantly progressing until 2002, the last available statistic. The years 1989-1992 were devoted to the switch from air freight to sea transport. These exports of around $2500 \mathrm{t}$ in 1992 or 1993 would be 4.5 times greater ten years later. The expansion mainly occurred after 1994 , while the exports of the neighbouring countries, which had a longer tradition in this field than Côte d'Ivoire, stagnated or declined.
The rapid growth of Côte d'Ivoire's exports is due to several favourable factors, particularly the presence of a shoreline, which enabled the development of ship transport, much less costly than by plane, and a bulk effect created by exports of over $300000 \mathrm{t}$ of bananas and pineapples.

Besides exports to Europe, mangoes from various origins are shipped to the Middle East and Gulf States. But due to the lack of freight capacities, the quantities exported remain modest.

\subsection{The varieties exported}

Amélie for a long time was the mainstay of exports from Mali, Burkina Faso and Côte d'Ivoire. In Mali, from 1971, experimental shipments of coloured mangoes were made with CNRF fruits. Importers were very satisfied with these mangoes and asked for more, which made up the developers' minds to encourage planting them. This was the start of the export of coloured mangoes, which would take on increasing importance as time went by. However, while consumption of mangoes was becoming more accessible in Europe, the demands of business were telling, and the choice of varieties was gradually reduced. After the green skin varieties (with the exception of Amélie), the
Figure 3.

Development in mango exports by the main producer countries in West Africa, excluding Côte d'Ivoire, from 1976 to 2002 
small or big fruit coloured varieties ${ }^{3}$ were eliminated.

In northern Côte d'Ivoire, until 1991 exports covered a range including Amélie, Kent, Keitt, Palmer, Zill, Haden, Valencia and Smith. The switch from aeroplane to ship eliminated rapid maturing varieties such as Valencia and Zill. Smith was not so highly rated because of physiological problems - precocious growth of roots in the pulp or jelly seed at the apex. Nor is its appearance always very attractive in northern Côte d'Ivoire. Haden, which has a magnificent appearance, has never been produced on a large scale. Exporter demand has therefore focused on Amélie, at the start of the season, and on Kent, Keitt and Palmer, with a preference for Kent.

\subsection{Packing techniques}

For the first shipments of mangoes, harvesting and packing were carried out directly in the fields. The shipper arrived at a plantation with their team of pickers, who collected the fruits for export, grouped them, cleaned them, sorted them, calibrated them and packed them on-site. They had to transport the packing equipment on site (tables, trestles, bowls, plastic sheets, protective cloth, water, etc.); the boxes were often soiled by the ground and rain seriously disrupted the work. The workers, who picked in the morning and packed in the afternoon, were tired and none too stringent in the sorting of the fruits they had picked themselves.

The next step consisted of packing the fruits manually, but in special rooms. In 1994 and 1995, over half of Ivory Coat's exports were still packed entirely manually, including the washing and grading operations.

Very quickly, mechanisation of packing became essential. In the big stations, the first circular grading machines were replaced by line grading machines with a much higher throughput. But recent changes affected

${ }^{3}$ Small fruit varieties: Ruby, Sensation, Dixon, for example. Big fruit varieties: Springfels, Davis-Haden, for example. other areas: improving the sorting and adding cold rooms to packing stations. Some exporters also practice soaking in hot water to combat anthracnose.

By the end of 2002, the majority of the equipped packing stations were in Côte d'Ivoire, between Ferkessédougou and Korhogo. There was also one in Odienné, in the West of the country, one in Maritime Guinea, one in Senegal and one in Sikasso, in southern Mali. In this country, which had been West Africa's pioneer in terms of mechanised packing, there are no complete big mechanised stations left, since the old stations at Bamako have been dismantled and dispersed to several exporters.

\section{References}

[1] Du Pavillon F., Le manguier à l'île Maurice et à l'île Bourbon, Pyrouman publications, Esclapon, 1954, 132 p.

[2] Sako B., Les habitudes alimentaires au Mali, Fruits 27 (5) (1972).

[3] Singh L.B., The mango, Leonard Hill Books Ltd., Londres, UK, 1960, 439 p.

[4] de Candolle A., Origine des plantes cultivées, Librairie Germer Baillière et Cie, Paris, France, 1883, réédition fac-similé : Laffitte, Marseille, France, 1984.

[5] Popenoe W., Manual of tropical and subtropical fruits excluding the bananas, coconut, pineapple, citrus fruits, olive and fig, Hafner Press, Div. Macmillan Publ. Co., New York, USA, 1920.

[6] Ibn Battuta, Voyages. Tome II : de La Mecque aux steppes russes (1325-1353), récit de 1355, réédition : FM / La Découverte, François Maspero, Paris, France, 474 p., 1982, p. 87.

[7] Mauny R., Les siècles obscurs de l'Afrique Noire, Fayard, Paris, France, 1970.

[8] Fernandes V., Description de la côte occidentale d'Afrique (Sénégal au Cap de Monte, Archipels, 1506-1510), actualisé par Monod T., Teixeira da Mota A. et Mauny R., Centro de Estudos Da Guiné Portuguesa, $n^{\circ} 11$, Bissau, 1951.

[9] Caillié R., Voyage à Tombouctou (18241828), récit de 1830, réédition : FM / La 
Découverte, François Maspero, Paris, 1979, Tome I, 373 p., Tome II, 401 p.

[10] Monod T., Un catalogue des plantes de Richard-Toll (Sénégal) en 1824, Bul. Ifan 13 (4) (1951) 1281-1298.

[11] Mauny R., Notes historiques autour des principales plantes cultivées d'Afrique de l'Ouest, Bull. Ifan 15 (2) (1953) 684-730.

[12] Binger L.G., Du Niger au golfe de Guinée par le pays de Kong et le Mossi (1887-1889), Tome 1 et 2, Paris, Hachette, 1892, réédition : Mémoires de la Société des africanistes,
Musée de l'Homme, Tome II, Paris, France, 1980 , pp. 330 et $362-365$.

[13] Sébire A. (R.P.), Les plantes utiles du Sénégal, J.B. Baillière et fils, Paris, France, 342 p., 1899, pp. 79-80.

[14] Toutée G.I., Du Dahomé au Sahara, la nature et l'homme, A. Colin et Cie, Paris, France, 272 p., 1899, pp. 54-58.

[15] Pobéguin H., Essai sur la flore de la Guinée française, Augustin Challamel, Librairie maritime et coloniale, Paris, France, 1906.

\section{El mango en el África Occidental francófona.}

Resumen - Introducción. El mango es un árbol muy apreciado en África Occidental por sus frutos y su sombra aunque su introducción en este continente es relativamente reciente. El artículo narra la historia de su expansión en la zona. La expansión del mango en África Occidental. Originario de la India, el mango fue observado por primera vez en África Occidental en Senegal, en 1824. Fue a finales del siglo XIX cuando los mangos experimentaron una difusión significativa, sobre todo en las zonas costeras. Su extensión se volverá importante durante la primera mitad del siglo XX. Un mango Amélie introducido en Malí hacia 1890 fue el origen de numerosas plantas injertadas que se difundieron ampliamente por los países limítrofes. A fines de los años cuarenta, se fueron estableciendo colecciones en toda la zona y, durante la década de 1970-1980, cada país del África Occidental francófona poseía, como mínimo, una colección de mangos. Evolución de las exportaciones. Malí fue el primer país que exportó, a finales de los años sesenta, mangos a Europa. Más tarde lo hicieron Burkina Faso, Guinea, Senegal y, sobre todo, Costa de Marfil, cuyas exportaciones, de unas $2500 \mathrm{t}$ a principios de los años noventa, se multiplicaron por 4,5 en el 2000. Este rápido crecimiento de las exportaciones de Costa de Marfil se vio favorecido por la existencia de una fachada marítima y del efecto de masa creado por las exportaciones de banano y piña. Durante mucho tiempo la variedad Amélie constituyó la parte fundamental de las exportaciones de Malí, Burkina Faso y Costa de Marfil. Sin embargo, a partir de 1971, se realizaron con éxito envíos experimentales de mangos colorados. Al irse extendiendo el consumo de mangos en Europa, la elección varietal fue reduciéndose progresivamente: Amélie, al principio de campaña, seguido de Kent, Keitt y Palmer. Paralelamente a esta evolución varietal, fueron modernizándose las técnicas de acondicionamiento.

Africa de habla francesa / Mangifera indica / introducción de plantas / distribución geográfica / exportaciones 